\title{
Paleoecology of the Permian (Wolfcampian) Phylloid Alga Calcipatera from an In Situ Occurrence in Kansas, U.S.A.
}

\author{
Robert S. Sawin ${ }^{1}$ and Ronald R. West ${ }^{2}$ \\ ${ }^{1}$ Kansas Geological Survey, 1930 Constant Avenue, Lawrence, Kansas 66047 \\ ${ }^{2}$ Department of Geology, Kansas State University, Manhattan, Kansas 66506
}

\begin{abstract}
In situ occurrences of the calcareous marine phylloid alga Calcipatera cottonwoodensis in the Permian Cottonwood Limestone Member (Beattie Limestone) occur in Greenwood County, Kansas, in association with platy algal packstones, which are the phylloid algal facies most commonly described in the literature. The in situ algal facies occurs in the upper $0.45 \mathrm{~m}$ of an exposure where it is overlain and underlain by algal packstones composed of transported and broken fragments of Calcipatera cottonwoodensis.

Calcipatera cottonwoodensis colonized coarse carbonate sands or carbonate mud substrates. During growth, carbonate mud accumulated in the cup-shaped thalli, and death followed when the rate of sedimentation exceeded the rate of algal growth. The three lithologies-substrate, cup-filling, and smothering - are easily recognized on polished surfaces.

Other members of the Calcipatera cottonwoodensis benthic community are Shamovella, encrusting and boring algae, foraminiferids, fenestrate and ramose bryozoans, brachiopods, bivalves, gastropods, trilobites, ostracodes, and echinoids. This occurrence and biotic association compares well with those described by Toomey (1976) and Wahlman $(1988,2002)$ from the Permian (Wolfcampian) of West Texas.
\end{abstract}

\section{Introduction}

The Cottonwood Limestone Member (Beattie Limestone) in Greenwood County, Kansas, contains in situ remains of the calcareous marine phylloid alga Calcipatera cottonwoodensis described by Torres et al. (1992). The term phylloid was introduced by Pray and Wray (1963) to describe membranous leaflike calcareous algae found in late Paleozoic rocks. Phylloid means "leaflike" or "resembling a leaf" and, according to Pray and Wray (1963, p. 209), has no implication as to the growth habit of the algae. Codiacean genera Eugonophyllum, Calcifolium, and Ivanovia, and the rhodophycean genus Archaeolithophyllum are Pennsylvanian and Permian algae to which the term phylloid is usually applied. Anchicodium also has been included in this group by some workers (Konishi and Wray, 1961; Laporte, 1962; Crowley, 1969), but other workers (Baars and Torres, 1991; Torres and Baars, 1992; and Torres et al., 1992) have clearly demonstrated that Anchicodium is "cylindrical and branching," as originally described by Johnson (1946), and thus not a phylloid alga. Two growth habits have been recognized for
Archaeolithophyllum: an encrusting form, A. lamellosum (Wray, 1964; Wahlman, 1988, 2002) and an erect "phylloid" form for A. missouriense (Wahlman 1985, 1988, and 2002). The growth habit of Calcifolium has been inferred, but in situ evidence is undocumented in the literature. Indeed, Calcifolium may be a sponge (Torres, 1995). Torres $(1995,1997)$ documented the cup-shaped, cyathiform thalli of Ivanovia and Eugonophyllum and noted the morphological similarity of the thalli of these two genera to the fossil taxon Calcipatera and the extant taxon Udotea cyathiformis. Elias (1963) discussed the habitat and mound-building tendencies of Ivanovia in the Pennsylvanian of the Paradox basin. Cross and Klosterman (1981, p. 48) described in situ phylloid algal thalli from the Virgilian of New Mexico with "rare occurrences of preserved internal structures," which were "preserved erect in growth habit" and "suggest a taxonomic similarity to the codiacean genus Eugonophyllum." Based on well-preserved internal structures, Kirkland et al. (1993) confirmed Cross and Klosterman's tentative identification as Eugonophyllum. 
Wahlman (1988, p. 184-186) recognized two main phylloid algal growth forms that commonly occur next to each other in his Zone IV phylloid algal bafflestone/ boundstone in the Permian basin of West Texas and New Mexico. The most common was sinuous to nearly horizontal, prostrate plates that, when identifiable, were Eugonophyllum or Ivanovia. Forms, identifiable as Archaeolithophyllum, were in situ curved to U-shaped plates with an orientation in common with adjacent plates suggesting an ecological response such as phototaxis. Babcock (1977) proposed a similar interpretation for clusters of open conical phylloid algae in the Middle Permian Capitan reef of the Guadalupe Mountains, West Texas.

In situ erect thalli of Calcipatera cottonwoodensis in the Cottonwood limestone in Greenwood County, Kansas, occur at only one known locality (figs. 1 and 2). The Cottonwood Limestone Member (Beattie Limestone, Council Grove Group, Wolfcampian Series, Permian System) is a lithostratigraphic carbonate unit that can be traced from southeastern Nebraska to Greenwood County, Kansas. South of Greenwood County, it is an interbedded limestone and calcareous shale (Laporte, 1962).

A unit of stacked in situ Calcipatera approximately 45 $\mathrm{cm}$ thick is situated near the upper part of the exposure (fig. 2a). This unit is underlain and overlain by fragmental algal packstones. The lower one is particularly typical of most phylloid algal occurrences (fig. 2b), and it forms the most conspicuous unit of the exposure. As described by Laporte (1962, p. 531), the thin, wavy, plate-like thalli are generally oriented parallel to bedding, and in weathered relief, give the rock an irregular, crenulated texture-a texture often described as a pile of potato-chips or cornflakes. At this exposure, the algal packstone is referred to as an accumulational occurrence, and the in situ unit is referred to as a constructional occurrence (Samankassou and West, 2002, 2004).

Laporte (1960, locality 42), who previously studied the Cottonwood limestone at this locality, did not report the in situ Calcipatera. Laporte (1962) identified the abundant broken fragments of Calcipatera as Anchicodium, but noted that the platy external shape did not agree with Johnson's (1946) original description of Anchicodium as being cylindrical and branching. Torres et al. (1992) discussed the morphology and taxonomy of the phylloid algae in the Cottonwood limestone.

Torres et al. (1992) reconstructed an in situ Calcipatera life assemblage. Such in situ occurrences probably represent patchy distributions analogous to some present-day algae. Large (up to $60 \mathrm{~mm}$ ) fragments of Calcipatera compose the algal packstones that may occur between the in situ patches.

The purpose of this paper is to provide some insight into the ecology of Calcipatera, its role in marine benthic communities, and the significance of this occurrence in terms of preservation, gross morphology, structure, and potential mound-building capabilities. A phylloid algal community from the Hueco Limestone (Permian) in West Texas (Toomey, 1976) is compared to the Cottonwood limestone occurrence.

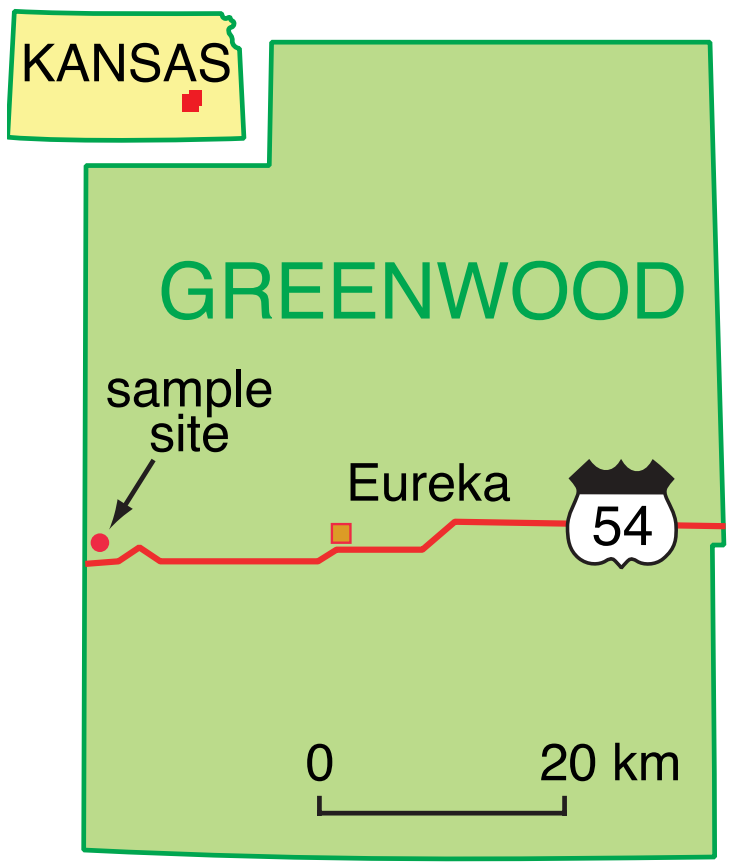

FIGURE 1-Geographic location of in situ Calcipatera occurrence. Sample site is a roadcut on the north side of U.S. Highway 54, $0.5 \mathrm{~km}$ east of the county line (SE SE SW sec. 3, T. 26 S., R. 8 E., Greenwood County, Kansas) (from Torres et al., 1992; used with permission of the Journal of Paleontology). 


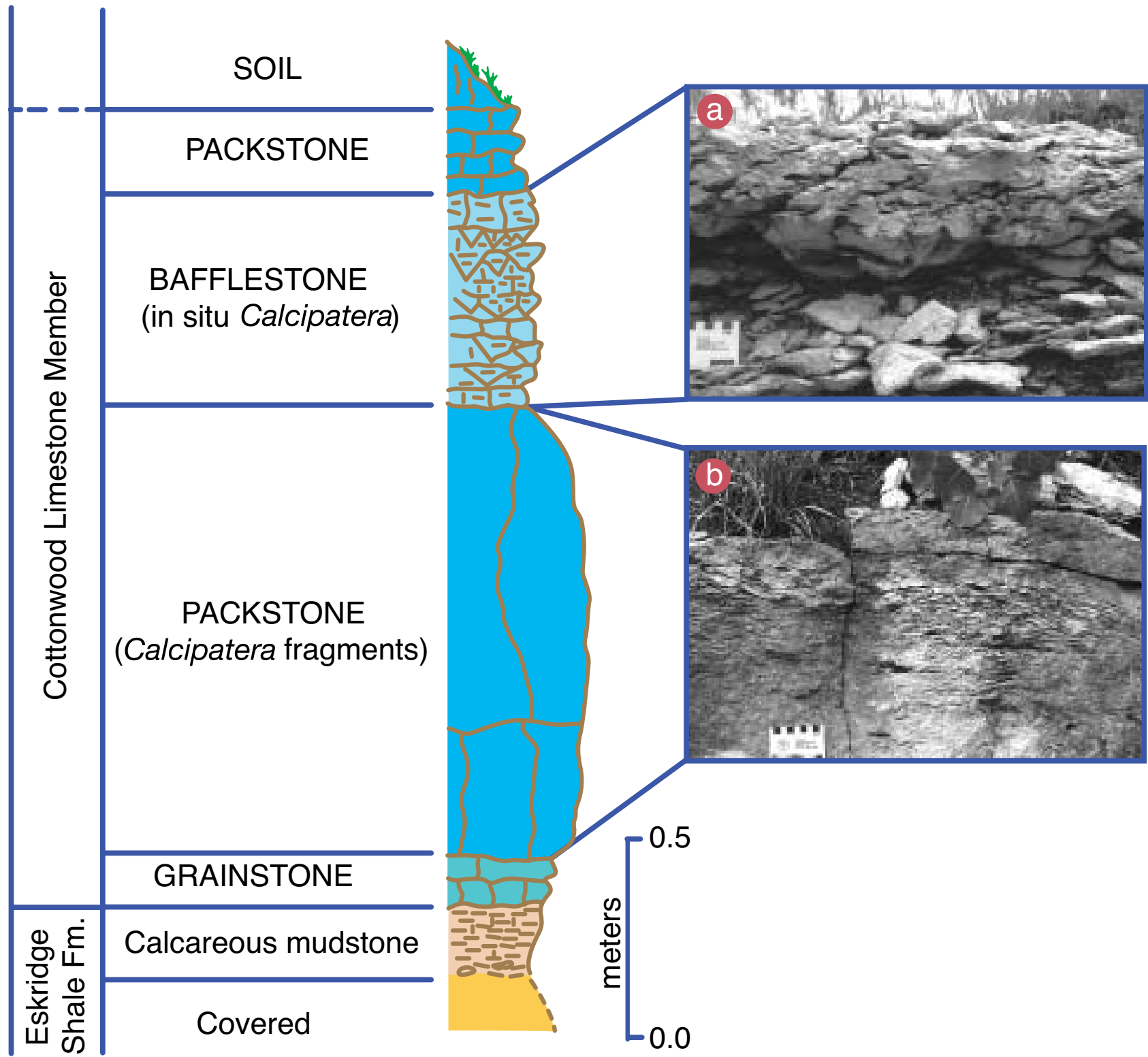

FIGURE 2-Graphic section at sample site. (a) Bafflestone containing in situ Calcipatera cottonwoodensis. (b) Platy algal packstone containing Calcipatera fragments. (Modified from Torres et al., 1992; used with permission of the Journal of Paleontology).

\section{Methods}

The exposure at this locality was measured and described noting particularly the form of the algal (Calcipatera) thalli, their association to each other, the associated biota (both attached encrusters and free-living epibiota), and the associated lithologies (three are recognized) that occur below, within, and above the interval bearing the upright, in situ, algal thalli. Oriented blocks were removed for laboratory examination. Polished sections, thin sections, and acetate peels were prepared, and along with numerous hand specimens, were studied to document the phylloid algal growth form, associated biota, and associated lithologies. Point counts, using the method of Chayes (1949), were made of thin sections from the three different lithologies. The general algal growth form was further documented by reconstructing a series of sections through an individual thallus. These serial sections formed the basis for the reconstruction of Calcipatera cottonwoodensis in Torres et al., 1992, reproduced here as fig. 3. For more details on the methods of study, see Torres et al. (1992). Differences between the three basic lithologies recognized in this study are illustrated by the point count data included in tables 1 and 2. The results of our studies are, in general, compatible with those presented by Laporte $(1960,1962)$ for the Cottonwood limestone at this locality, but our focus was on the in situ algal growths rather than the more resistant and conspicuous bed of platy algal packstone that was the focus of Laporte's studies. 


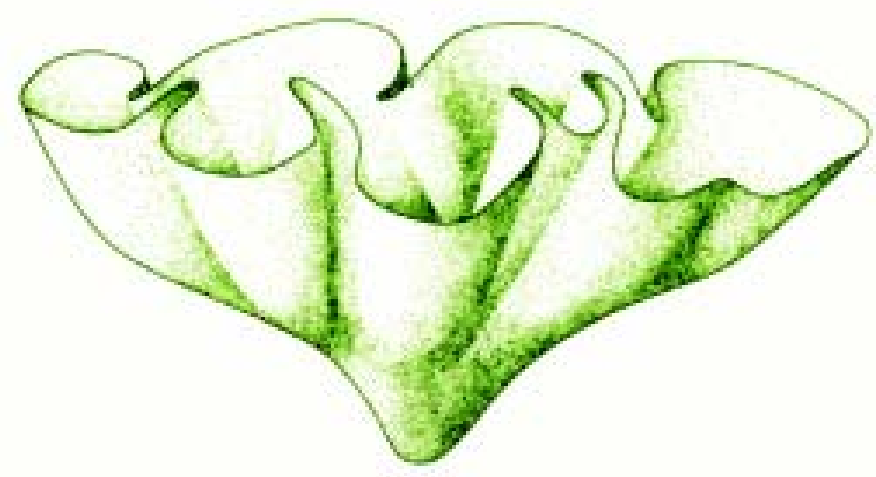

FIGURE 3-Reconstruction of Calcipatera cottonwoodensis. Thallus is about $13.5 \mathrm{~cm}$ across and $4.2 \mathrm{~cm}$ high (from Torres et al., 1992; used with permission of the Journal of Paleontology).

\section{Growth Form}

Based on field and laboratory observations, we conclude that Calcipatera displayed a gregarious habit with dense growths of overlapping thalli that formed a continuous to patchy canopy above the substrate. Baffling by the erect algal thalli caused fine carbonate sediments to settle around the alga and fill the cup-shaped thalli. Skeletal fragments of the alga, epiphytes, and mobile organisms also settled on, within, and around the in situ growths. As sediment filled the cup-shaped thalli, growth of the thalli continued upward, and at the same time, new thalli established themselves on the carbonate mud substrate within the cups, producing stacked buildups of Calcipatera (fig. 2a). Growth of an individual thallus ceased when overtaken or shaded by a dominate (larger) thallus (fig. 4), or when completely buried by sediment.

As pointed out by Torres et al. (1992), placement of Calcipatera and other Paleozoic algae in a taxonomic hierarchy constructed for living algae is arbitrary; however, there are many Holocene algal genera with somewhat similar growth forms and methods of substrate attachment to which Calcipatera can be compared. Based strictly on gross morphology (cup-shaped leafy thallus), Calcipatera most closely resembles the Holocene genera of brown algae (Phaeophyta) Lobophora and Padina (especially Padina sanctae-crucis). In Padina, the only brown alga that calcifies (Littler et al., 1989), calcification is limited to the surficial layer, perhaps as a result of the removal of carbon dioxide by photosynthesis. The green alga (Chlorophyta) Udotea cyathiformis has a calcified funnel- or cup-shaped thallus attached to a small single stalk (Littler et al., 1989). Other Holocene green algal genera with folded, leafy thalli include several species of Ulva and Avrainvillea. Konishi and Wray, 1961, compared the growth form of Eugonophyllum, another cyathiform alga (Torres, 1997), to the Holocene brown algal genus Thalassiophyllum. Thus, the growth form of Calcipatera, as illustrated by Torres et al. (1992), and further supported by this study, is known from extant algae from several different taxonomic groups.

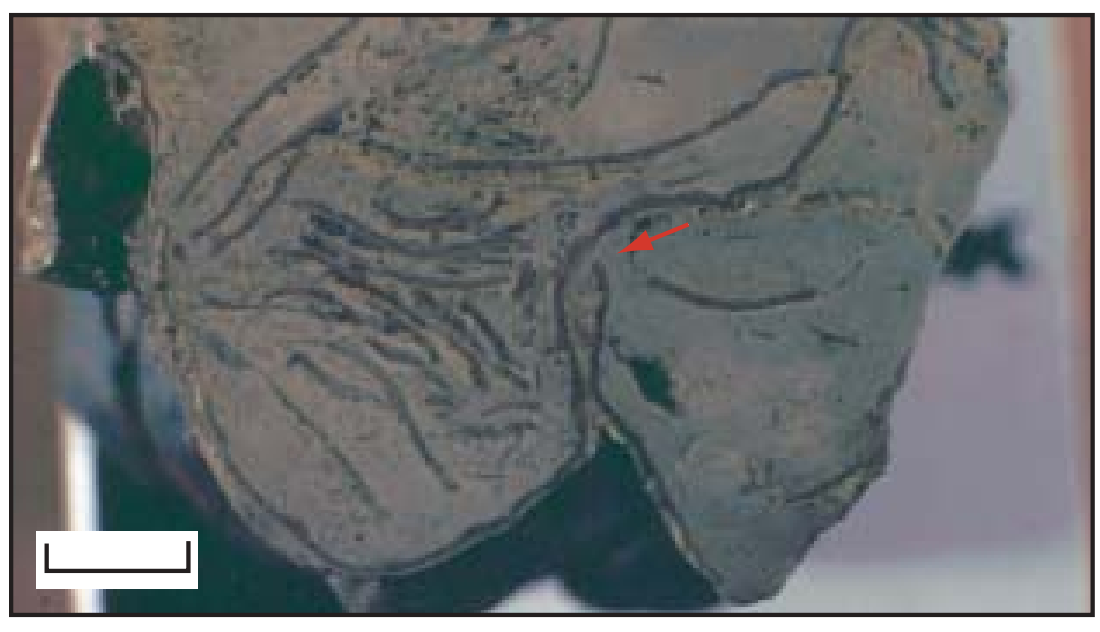

FIGURE 4-Polished specimen showing cross sectional view of in situ Calcipatera in growth position (growth was from base to top of photo). The cup-shaped thalli are filled with carbonate mud, skeletal grains, and fragments of the alga. Growth of the individual thallus on the right was inhibited (arrow) by the thallus on the left. Scale bar $=1 \mathrm{~cm}$. 


\section{Substrates and Sedimentation}

Within the algal bafflestone, three different lithologies are associated with the in situ erect algal thalli. They are (1) the sediment upon which the colonizing individuals grew (substrate), (2) sediment that filled the upright thalli and upon which subsequent individuals grew (cup-filling sediment), and (3) sediment that smothered or halted growth because sedimentation rates exceeded the rate of upward algal growth (smothering sediment). Figure 5 illustrates the occurrence within, and relationships between, these three lithologies in the algal bafflestone. More than one colonization event occurred at the study site, so the three recognized lithologies are repeated vertically.

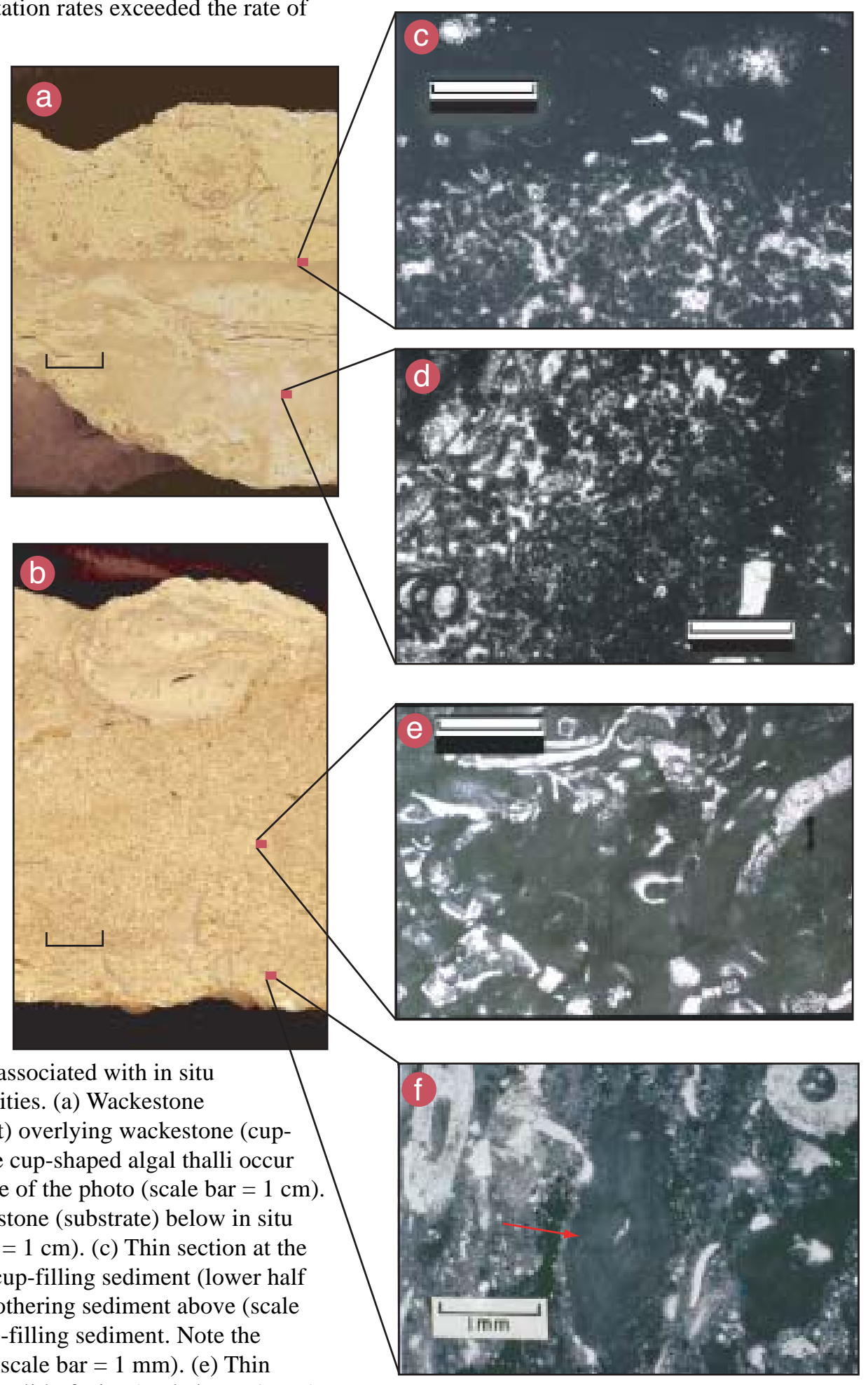

FIGURE 5-Lithologies associated with in situ Calcipatera communities. (a) Wackestone (smothering sediment) overlying wackestone (cupfilling sediment). The cup-shaped algal thalli occur along the bottom edge of the photo (scale bar $=1 \mathrm{~cm}$ ). (b) Wackestone-packstone (substrate) below in situ algal thalli (scale bar $=1 \mathrm{~cm}$ ). (c) Thin section at the contact between the cup-filling sediment (lower half of photo) and the smothering sediment above (scale bar $=1 \mathrm{~mm}$ ). (d) Cup-filling sediment. Note the peloidal appearance (scale bar $=1 \mathrm{~mm}$ ). (e) Thin section of the substrate lithofacies (scale bar $=1 \mathrm{~mm}$ ).

(f) Shamovella (arrow) in the substrate lithofacies. 


\section{Substrate}

Based on the grain size and the data given in tables 1 and 2 , the incipient substrate (fig. $5 \mathrm{~b}$ and $5 \mathrm{e}$ ) is a coarsegrained wackestone-packstone $(53.4 \%$ skeletal grains, $46.6 \%$ carbonate mud). The carbonate mud matrix has been recrystallized to microspar. Of the three lithologies associated with the in situ algae, the insoluble content is highest in this one $(6.4 \%$, see table 2$)$. Quartz or similar insoluble minerals were not encountered in the point count of constituents of the substrate lithology; however, suggesting that these insolubles are probably clay minerals seems reasonable, although the mineralogy was not determined.
The most abundant skeletal grains in the substrate lithofacies are bryozoan and echinoderm fragments (19.5\% and $12.0 \%$, respectively, of the total rock constituents; see table 1). Shamovella, now considered a senior synonym of Tubiphytes (Riding, 1993), is currently considered to be a combination of a non-preserved softbodied organism and a cyanobacterial envelope as stated by Senowbari-Daryan and Flugel, 1993 (see Wahlman, 2002 for review). Shamovella composes $7.5 \%$ of the substrate constituents and occurs encrusting and binding other skeletal grains (fig. 5f). Nearly as abundant as Shamovella are clasts of Calcipatera fragments and the cup-filling lithology (7.3\%, table 1$)$. Carbonate mud, the most abundant rock constituent in the substrate

TABLE 1. Percentage of total rock constituents (from point-count method of Chayes, 1949).

\begin{tabular}{|c|c|c|c|}
\hline Rock Constituent & Substrate & Cup-filling Sediment & Smothering Sediment \\
\hline Calcipatera fragments & 0.0 & 6.1 & 1.4 \\
\hline Clasts of Calcipatera fragments & 7.3 & 0.0 & 0.0 \\
\hline \multicolumn{4}{|l|}{ and cup-filling sediment } \\
\hline Shamovella & 7.5 & $1.6^{\mathrm{a}}$ & 2.9 \\
\hline Mobile textulariine foraminifers & 0.5 & $1.0^{\mathrm{a}}$ & 0.0 \\
\hline Encrusting foraminifers (Tuberitina) & 0.0 & $0.07^{\mathrm{a}}$ & 0.1 \\
\hline Bryozoan (fenestrate, ramose) & 19.5 & $0.1^{\mathrm{a}}$ & 1.3 \\
\hline Echinoderms & 11.2 & $0.5^{\mathrm{a}}$ & 0.9 \\
\hline Echinoid spines & 0.8 & 0.0 & 0.0 \\
\hline \multicolumn{4}{|l|}{ Impunctate brachiopods } \\
\hline Fragments & 0.30 & $0.07^{\mathrm{a}}$ & 0.6 \\
\hline Whole, articulated & 0.1 & $0.2^{\mathrm{a}}$ & 0.2 \\
\hline Whole, disarticulated & 0.07 & 0.0 & 0.0 \\
\hline Pseudopunctate brachiopods & 0.07 & 0.0 & 0.0 \\
\hline Trilobites & 1.1 & 0.0 & 0.0 \\
\hline Ostracodes & 0.2 & $0.3^{\mathrm{a}}$ & 0.2 \\
\hline Bivalves & 0.2 & 0.0 & 0.0 \\
\hline Unidentifiable skeletal grains & 4.6 & $1.0^{\mathrm{a}}$ & 5.4 \\
\hline Hematite? crystals & 0.0 & 0.0 & 0.1 \\
\hline Peloids & 0.0 & 1.3 & 0.0 \\
\hline Sparite & 0.0 & 2.8 & 0.0 \\
\hline Carbonate mud & 46.6 & 85.0 & 86.7 \\
\hline TOTAL & 100.0 & 100.0 & 99.8 \\
\hline
\end{tabular}

\footnotetext{
${ }^{a}$ Medium-sized carbonate grains
} 
TABLE 2. Substrate and sediment constituents from point-count data (see table 1).

\begin{tabular}{lccc}
\hline \hline & Substrate & Cup-filling Sediment & Smothering Sediment \\
\hline Soluble Components & & & \\
Skeletal grains & $53.4 \%$ & $10.9 \%$ & $13.2 \%$ \\
Carbonate mud & $46.6 \%$ & $85.0 \%$ & $86.7 \%$ \\
Sparite & $0.0 \%$ & $2.8 \%$ & $0.0 \%$ \\
Peloids & $0.0 \%$ & $1.3 \%$ & $0.0 \%$ \\
Insoluble Components $^{\mathrm{a}}$ & $6.4 \%$ & $1.7 \%$ & $5.2 \%$ \\
\hline
\end{tabular}

ansoluble components represents percent not dissolved by $10 \% \mathrm{HCl}$.

lithofacies, fills small pores in the wackestone-packstone. However, carbonate mud is much less abundant in the substrate lithofacies than in the other two lithologies associated with the in situ algae (table 1).

The substrate colonized by Calcipatera was composed of skeletal grains, and in some cases, clasts of other lithologies, that were probably bound together into a relatively stable surface. A significant factor in the stabilization of this grain-supported substrate may have been the partial binding of skeletal grains by microbial activity; however, peloids, often created by microbial activity (Chafetz, 1986), were not observed in this lithology (see table 1). There is evidence that Shamovella encrusted some of the hard skeletal fragments. Sediment binding, primarily by non-preserved microbial activity such as encrustations and cementation (Chafetz, 1986), probably stabilized the substrate. To some extent Shamovella may have helped stabilize the otherwise loose substrate and provided a more suitable surface for Calcipatera colonization because it occurs encrusting Calcipatera fragments. Although phylloid algae appear to have been opportunistic (Wahlman, 2001), some sediment binding may have been beneficial. Conversely, Shamovella may not have inhabited the area until Calcipatera had colonized the substrate. From our studies, it is impossible to determine who colonized this substrate first: microbes, Shamovella, or Calcipatera.

At this study site, Calcipatera apparently grew on both coarse carbonate sand and carbonate mud substrates and fits Konishi's (1961) paleoecologic interpretation of Anchicodium (Calcipateria?), as summarized by Crowley (1969, p. 42); similar substrates have been reported for the coralline alga Archaeolithophyllum by Wray (1964).

\section{Cup-filling Sediment}

The lithology filling the thalli of Calcipatera (cupfilling sediment) (fig. 5a and 5d) is a wackestone dominated by recrystallized carbonate mud $(85.0 \%$, see table 2), with skeletal grains making up $10.9 \%$ (6.1\% of these skeletal grains are fragments of Calcipatera, see table 1). The insoluble content is low (1.7\%, table 2). Additionally, peloids and sparry calcite are present - two constituents that are absent in the other two lithologies (see tables 1 and 2). Excluding Calcipatera fragments, skeletal grains $(4.8 \%$, table 1$)$ are mostly medium-sized. The matrix has a clotted or peloidal appearance (fig. 5c and 5d) that varies from loosely packed peloids to a more densely packed, homogenous carbonate mud. These peloids are similar to pellets in that they are rounded or elliptical aggregates that range from 0.003 to $0.15 \mathrm{~mm}$ in diameter and are devoid of internal structure. The poorly defined boundaries of these peloids have irregular, indistinct outlines that appear as aggregates of carbonate mud supported by a matrix of re-crystallized carbonate mud. Chafetz (1986) has described similar peloids as the product of microbial cementation (see also Wahlman, 1988, 2002). The density of packing is greatest at the bottom of the thalli cup, becoming loosely packed near the top. Loose packing also was observed under algal fragments or other skeletal fragments that had fallen into the cup.

The carbonate mudstone, now re-crystallized, within the erect Calcipatera cups was probably the result of baffling by the gregarious Calcipatera thalli. Carbonate mud (less than 4 microns) settled and accumulated within the cup-shaped thalli as energy decreased. Fragments of Calcipatera within the cups (fig. 4) were probably broken from the erect thalli during turbulent episodes. Increased packing caused by compaction destroyed the outline of the peloids, suggesting that these peloids result from recrystallization or clotting during sedimentation or diagenesis, rather than being fecal in origin. Crowley (1969) observed similar textures in the Wyandotte Limestone (Pennsylvanian) where areas beneath supporting algal fragments had been sheltered from compaction. Geopetal pelletal sediment was reported within these sheltered voids, on the upper surfaces of broad fragments of phylloid algae, and within erect conical-vase forms of phylloid algae by Cross and 
Klosterman (1981). Sparry calcite (sparite of tables 1 and 2) filled the shelter cavities created by algal and other skeletal fragments and also occurs as replacement or recrystallization of skeletal grains. Terrigenous silt and clay-sized particles accumulated under the erect thalli and in some voids, suggesting these particles sifted into empty spaces during times of increased sedimentation.

\section{Smothering Sediment}

The lithology immediately overlying the in situ Calcipatera community (smothering sediment) (fig. 5a and $5 \mathrm{c}$ ) is a wackestone composed primarily of recrystallized carbonate mud $(86.7 \%$, tables 1 and 2$)$. The percentage of skeletal grains in this lithology $(13.2 \%)$ is slightly higher than in the cup-filling lithology, and the insoluble content $(5.2 \%)$ approaches that found in the substrate lithology (6.4\%). Unidentified skeletal grains (5.4\%), Shamovella (2.9\%), and Calcipatera fragments $(1.4 \%)$ are the dominant skeletal components.
The contact between the smothering and cup-filling sediments is frequently a sharp, irregular (but nonerosional) surface, which is easily recognized (fig. 5a and $5 \mathrm{c}$ ). As noted above, there are two, and sometimes three, separate intervals of in situ Calcipatera communities within the bafflestone at this locality. This suggests that growth of the in situ Calcipatera thalli was interrupted from time to time by sediment influx. The lithology overlying each in situ Calcipatera event is referred to as the smothering sediment because there is no evidence of in situ Calcipatera growth within this lithology. This lithology suggests that either a sudden influx of sediment terminated Calcipatera growth, or that the rate of sedimentation exceeded the rate of upward algal growth. The major differences between the two lithologies are the low percentage of skeletal grains and very high percentage of carbonate mud in the smothering sediment. The sudden influx of this smothering sediment was probably the result of storm deposition or shifts in the depositional environment.

\section{Paleoecology}

Calcipatera, an erect calcareous alga with a cupshaped thallus, grew gregariously to form a dense meadow above the substrate. The living thalli probably attached to the substrate by rhizoids (Torres et al., 1992) and grew to a height of about $10 \mathrm{~cm}$. Calcipatera attached to both skeletal-sand and carbonate-mud substrates, and when the rate of sedimentation exceeded the rate of upward algal growth, the community died. The broad thin thalli of Calcipatera and the high percentage of carbonate mud (tables 1 and 2) indicate that Calcipatera probably could not have withstood a high degree of wave or current turbulence. Thus, Calcipatera inhabited a paleoenvironment within the photic zone, and below wave base or in protected areas on a shallow epicontinental shelf.

In areas where wave and current turbulence were low, Calcipatera could have probably existed in relatively shallow water. Shallow water and increased light favored maximum algal growth and probably a higher rate of carbonate production (Crowley, 1969). Konishi and Wray (1961, p. 664) interpreted water depths for Eugonophyllum as "probably less than one fathom" and "based on analogy with Recent calcareous Codiaceae" (the family to which Calcipatera was assigned by Torres et al., 1992), "suggest that it did not commonly live at depths greater than 100 feet."

Once Calcipatera was established, it tended to be selfperpetuating - that is, produced abundant bioclastic debris, and baffled, trapped, and stabilized carbonate sediment. The amount of carbonate mud produced by Calcipatera is unknown but could have been substantial if similar to the sediment contributions of such Holocene algae as Penicillus, Rhipocephalus, Udotea, and Acetabularia (Stockman et al., 1967). The baffling and trapping of carbonate mud by Calcipatera can be compared to the role performed by the modern sea grass Thallassia as described by Ginsburg and Lowenstam (1958).

Assuming Calcipatera was attached via a holdfast or similar structure, a stable substrate, although not required, might have been advantageous. Although extant calcareous green algae are known to grow on a variety of substrates, some initial stabilization may have been required for Calcipatera colonization and this could have been provided by nonpreserved microbial activity. Although this in situ occurrence of Calcipatera helped stabilize the substrate and baffled and trapped sediment, it did not produce a mound or moundlike structure at this locality.

Ball et al. (1977, p. 251) described a situation where Archaeolithophyllum occurred "in supposed growth position" at a single exposure of Winchell Limestone (Pennsylvanian) near Ranger, Texas, but evidence of mound buildup growth was lacking. Ball et al. (1977, p. 258) concluded, from this and other occurrences, that "phylloid algae were important sources of building material rather than important builders," rejecting the idea that phylloid algae are important bafflers, trappers, and binders of sediment and creators of bioconstructed mounds. However, it is important to note that what is described here and by Ball et al. (1977) in the Winchell Limestone are phylloid algal shelfal banks. Phylloid algal mounds are more typical of Wolfcampian shelf-margin 
settings as described by Wahlman $(1985,2002)$ and by Wahlman in Simo et al. (2000) and Simo et al. (2001) from the subsurface Permian basin and in the Hueco Mountains of West Texas. What Ball et al. (1977) described is what Samankassou and West $(2002,2004)$ would refer to as an accumulational mode of algal occurrence. In refuting this interpretation by Ball et al. (1977), Cross and Klosterman (1981) pointed out that the stromatolitic-bound phylloid algal mound complex in the Laborcita Formation (Permian): (1) have "demonstrable depositional relief of $2.5 \mathrm{~m}$ and probable maximum relief of about $10 \mathrm{~m}$ " (p. 46), (2) are dominated by the phylloid algae Eugonophyllum that is "preserved erect in growth habit" (p. 48), (3) are "unrelated to pre-existing topography" (p. 57), and (4) that "mound development was controlled by growth of erect phylloid algae, binding by stromatolites, trapping of carbonate mud, and penecontemporaneous submarine cementation" (p. 57). In that Eugonophyllum is now recognized as a cyathiform alga (Torres, 1997), these Permian algal mounds would be referred to as constructional mounds composed of cupshaped in situ algal growth forms as described by Samankassou and West (2002) for an occurrence in the Pennsylvanian of Kansas.

As suggested by Cross and Klosterman (1981), there are biologically constructed mounds (constructional occurrences of Samankassou and West, 2002) and parautochthonous occurrences of algal debris (accumulational occurrences of Samankassou and West, 2002). Additionally, there are different types of constructional occurrences (Samankassou and West, 2004). Forsythe (2003) studied the Virgilian and Wolfcampian limestones of the Hueco Mountains in West Texas and New Mexico. His studies indicated that
Archaeolithophyllum constructed low-relief structures, i.e. biostromes, but that Eugonophyllum and

Archaeolithoporella, along with microbes and marine cements, produced rigid frameworks with the cryptic habitats of an active reef.

At this locality in Greenwood County, Kansas, where Calcipatera occurs in growth position, and at other exposures of the Cottonwood limestone in the area, there is no obvious evidence of mounds or moundlike structures. Indeed, this is the only Cottonwood limestone locality, to our knowledge, where Calcipatera occurs in growth position. The platy algal facies, as reported by Laporte $(1960,1962)$, herein referred to as packstone, occurs at other localities. However, this occurrence of Calcipatera in life position, the work of Cross and Klosterman (1981), and the Pennsylvanian occurrence described by Samankassou and West (2002) suggests that cyathiform algae such as Eugonophyllum, Calcipatera, and some other types of phylloid algae were capable of mound construction, as documented by Forsythe (2003) for Eugonophyllum. It seems reasonable that the cupshaped thalli of such algae could have baffled and trapped sediment such that mound-like features were the result. Perhaps the absence of any mound-like structures at the locality of this study is the result of environmental perturbations (e.g., increased sedimentation) that smothered algal growth before any significant topographic relief (mounding) developed. Such environmental perturbations are supported by the fact that more than one colonization event by Calcipatera is preserved at this locality. Lack of vertical accommodation space and/or unlimited lateral growth space could have also precluded mound development.

\section{Calcipatera Community}

Examination of the outcrop at this locality suggests that dense growths of Calcipatera dominated this site and may have blanketed the substrate, creating a cryptic habit for a unique biotic association. Conclusions concerning this unique biotic association are based on the examination of (1) in situ specimens on the outcrop (figs. $2 \mathrm{a}$ and $6 \mathrm{a})$, (2) large blocks of the bafflestone with in situ Calcipatera thalli and associated lithologies in the laboratory (fig. 6b), (3) numerous (over 100) hand specimens of individuals and clusters of Calcipatera thalli weathered from the outcrop (figs. 6c-6j), (4) oriented polished surfaces of the bafflestone with in situ thalli of Calcipatera (figs. 4, 5a, 5b), and (5) oriented thin sections (figs 5c-5f).

Specimens of the brachiopod Crurithyris, in presumed life position, occur on the exterior of some thalli (fig. 7a). Whole (articulated and disarticulated) and fragmented shells of Crurithyris also occur in the cup-filling sediment. Minammodytes?, an encrusting foraminifer, occurs attached to the exterior of some thalli (fig. 7b). Another encrusting foraminifer, Tuberitina, is attached to the interior (fig. 7c), and also contributes to the skeletal fraction of the cup-filling sediment. Crurithyris and the encrusting foraminferids occur near the upper edges of the algal thalli. A fenestrate bryozoan, attached to the exterior, is nearly encased by an algal thallus (fig. 7d). Shamovella is found within the substrate as well as attached to the thalli. Mobile benthic textulariine foraminifers (fig. 7e) and gastropods (fig. 7f) also are associated with the community. Additionally, fragments of pseudopunctate brachiopod shells, bivalve shells, ostracodes, trilobites, and echinoids were observed on polished surfaces and in thin sections. These taxa do not appear to have contributed significantly to the fabric of the bafflestone. These associated organisms were either epiphytic on the phylloid algae or capable of surviving in the cryptic niches beneath or within the Calcipatera clusters. 

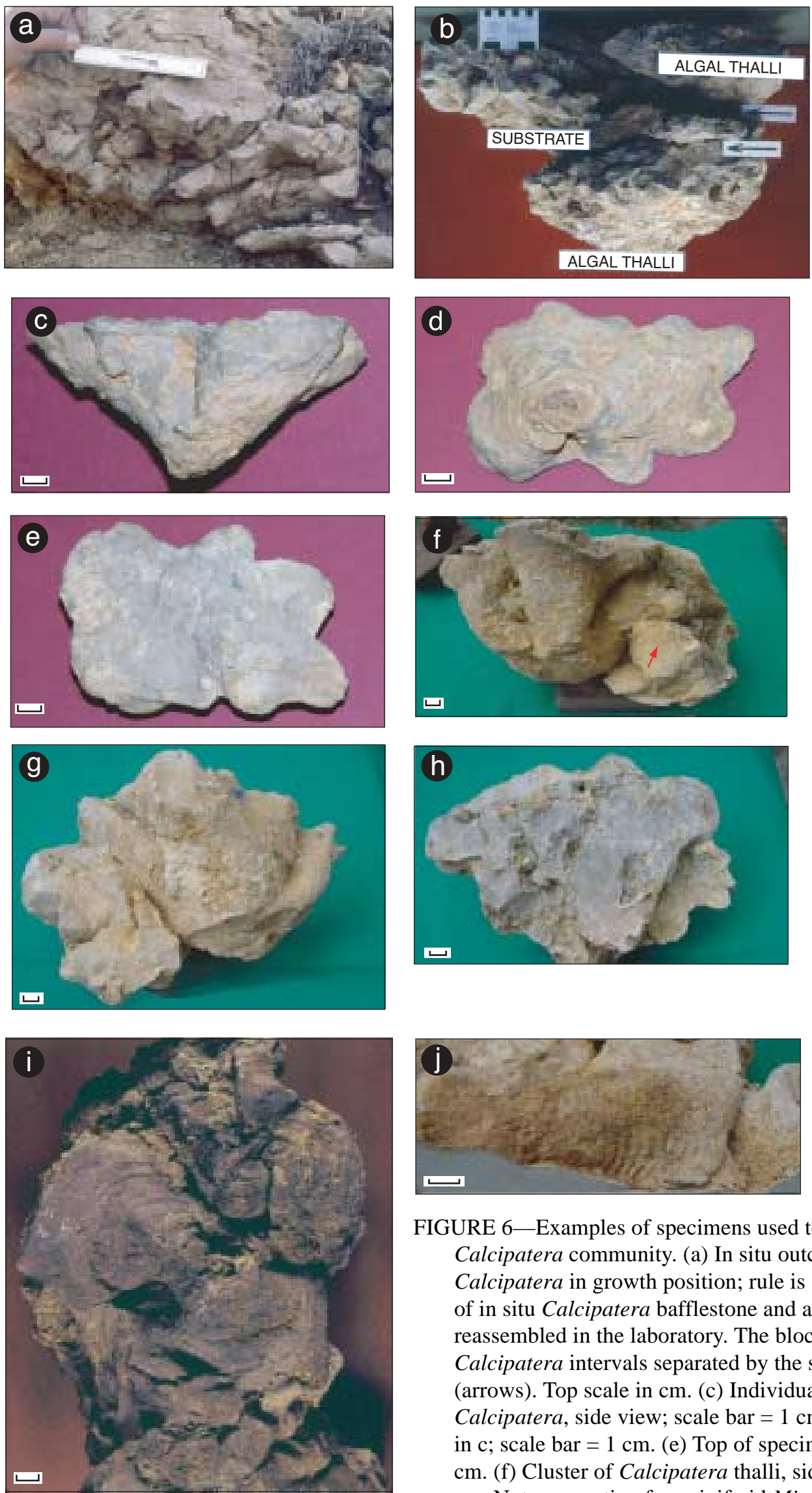

FIGURE 6-Examples of specimens used to reconstruct the

Calcipatera community. (a) In situ outcrop block of Calcipatera in growth position; rule is $15 \mathrm{~cm}$ long. (b) Block of in situ Calcipatera bafflestone and associated lithologies reassembled in the laboratory. The block represents two in situ Calcipatera intervals separated by the substrate lithology (arrows). Top scale in $\mathrm{cm}$. (c) Individual thallus of Calcipatera, side view; scale bar $=1 \mathrm{~cm}$. (d) Base of specimen in c; scale bar $=1 \mathrm{~cm}$. (e) Top of specimen in c; scale bar $=1$ $\mathrm{cm}$. (f) Cluster of Calcipatera thalli, side view; scale bar $=1$ $\mathrm{cm}$. Note encrusting foraminiferid Minammodytes? (arrow) on lower right of specimen. (g) Oblique view of base and side of specimen in $\mathrm{f}$; scale bar $=1 \mathrm{~cm}$. (h) Top of specimen in $\mathrm{f}$; scale bar $=1 \mathrm{~cm}$. (i) Base of a Calcipatera cluster; scale bar $=1 \mathrm{~cm}$. (j) Wrinkled underside of Calcipatera thalli; scale bar $=1 \mathrm{~cm}$. 

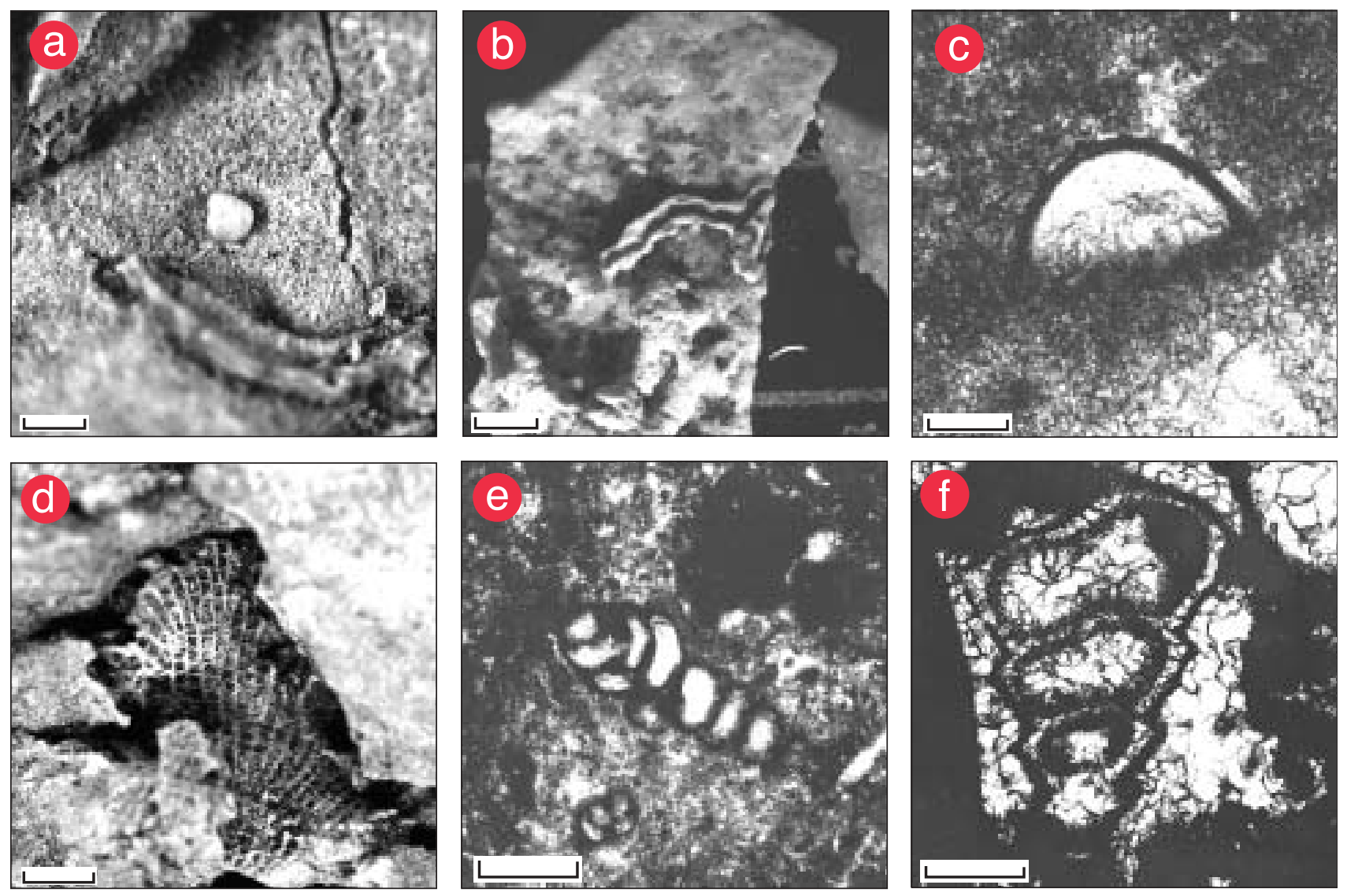

FIGURE 7-Selected biotic components associated with the Calcipatera community. (a) Crurithyris (scale bar $=1$ $\mathrm{mm}$ ), (b) Minammodytes? (scale bar $=1 \mathrm{~mm}$ ), (c) Tuberitina $($ scale bar $=0.1 \mathrm{~mm})$, (d) Fenestrate bryozoan (scale bar $=3 \mathrm{~mm}$ ), (e) Textulariine foraminifer (scale bar $=0.5 \mathrm{~mm}$ ), (f) Gastropod (scale bar $=0.5 \mathrm{~mm}$ ). The organisms in a - e appear to be attached to Calcipatera thalli.

The living Calcipatera community created a canopy above the substrate and attached to these algal thalli were encrusting algae, foraminifers, bryozoans, and the pedunculate brachiopod Crurithyris. Mobile foraminifers, ostracodes, trilobites, bivalves, gastropods, pseudopunctate brachiopods, and echinoids occupied available surrounding spaces. Because most of the available living space was occupied by the abundance of Calcipatera, the biotic diversity of this community is low.

It is likely that the organisms associated with this algal-dominated association were already adapted to the niches provided by the algal canopies. None of the preserved associated organisms is, to our knowledge, unique to this upper Paleozoic algal community. Thus, each of the associated organisms was probably adapted to a wide range of environmental conditions, only one set of which happened to occur in this algal-dominated community.

Fossils associated with the in situ growth of Calcipatera are similar those documented by Toomey (1976) for an algal-dominated marine community from the Hueco Limestone (Permian) of Texas. To help understand the role of the associated biota, they have been arranged in the ecological categories recognized by Toomey (1976):

\section{Autotrophs}

- erect codiacean alga Calcipatera

- encrusting non-calcified plants, cyanobacteria, and Shamovella

- encrusting and/or boring algae

\section{High Filters}

- agglutinated encrusting foraminifer Minammodytes?

- calcareous encrusting foraminifers Tuberitina, Tetrataxis

- fenestrate and ramose bryozoans

- pedunculate brachiopod Crurithyris

\section{Low-High Filters}

- mobile textulariine foraminifers

- bivalves

- pseudopunctate brachiopods 


\section{Collectors and/or Predators}

- echinoids

- trilobites

- ostracodes

- gastropods

Table 3 compares the Cottonwood limestone Calcipatera community to the Lower Permian Hueco Limestone phylloid algal occurrence, using the trophic categories of Toomey (1976). Of course, differences in data collection and analysis must be taken into account in the comparison of the two communities. Toomey (1976) dissolved $250 \mathrm{lbs}$ of the silicified phylloid algal rocks in dilute formic acid and examined 50 large thin sections and was able to obtain a relative estimate of biovolume. The Calcipatera community, because of its in situ occurrence, preservation, and non-silicified character, was studied differently as described in the "Methods" section above.

The Calcipatera community shares some general similarities with the phylloid algal community documented by Toomey (1976). The autotrophic phylloid algal genera are different, but the growth forms are quite similar. Agglutinated and calcareous foraminifers, bryozoans, and a single genus of pedunculate brachiopod

TABLE 3. Comparison of the Cottonwood limestone Calcipatera community to Toomey's (1976) Hueco Limestone phylloid algal occurrence.

\begin{tabular}{|c|c|}
\hline Calcipatera Community & Phylloid Algal Community (modified from Toomey, 1976) \\
\hline Autotrophs & Autotrophs \\
\hline Calcipatera & Ivanovia/Eugonophyllum \\
\hline Shamovella & (?) Tubiphytes (now Shamovella) \\
\hline Encrusting and/or boring algae & Girvanella \\
\hline High Filters & High Filters \\
\hline Minammodytes? & Minammodytes \\
\hline Tuberitina, Tetrataxis & Composita subtilita (Hall) \\
\hline Fenestrate and ramose bryozoans & Tuberitina, Tetrataxis \\
\hline \multirow[t]{4}{*}{ Crurithyris } & Ammovertella \\
\hline & Apterrinella? \\
\hline & Fenestrate bryozoans \\
\hline & Spirorbis \\
\hline Low-High Filters & Low-High Filters \\
\hline Mobile textulariine foraminifers & Monaxon sponge spicules \\
\hline Bivalves & Globivalvulina, nodosarids, and syzranids \\
\hline \multicolumn{2}{|l|}{ Pseudopunctate brachiopods } \\
\hline & Low Filters \\
\hline & Myalina \\
\hline & Astartella \\
\hline Collectors and/or Predators & Collectors \\
\hline Echinoids & Echinoid spines and plates \\
\hline Trilobites & Goniasma \\
\hline Ostracodes & Ostracodes \\
\hline \multirow[t]{9}{*}{ Gastropods } & Apachella and Anomphalus? \\
\hline & Collectors/Predator \\
\hline & Naticopsis \\
\hline & Predators/Collectors \\
\hline & Fish teeth and denticles \\
\hline & Predators \\
\hline & Metacoceras \\
\hline & Swallowers \\
\hline & Bakevillia \\
\hline
\end{tabular}


are found in each community. Low to high filter-feeding organisms common to both communities are mobile foraminifers and possibly bivalves. Echinoids, ostracodes, and gastropods are classified as collectors and/or predators in each community. Organisms found in the Hueco Limestone phylloid algal community that are not observed in the Cottonwood limestone Calcipatera community include ammonites, fish remains, encrusting polychaete worms, and sponges. Trilobites,

pseudopunctate brachiopods, and ramose bryozoans occur in the Calcipatera community but were not reported in the Hueco phylloid algal community described by Toomey (1976). Overall, in view of the different methods of data collection and analysis, the two communities seem to compare quite favorably. The occurrence of ammonites, sponges, and fish remains in the Hueco Limestone community could suggest communication with the open marine realm of the adjacent Orogrande basin.

\section{ACKNOWLEDGMENTS}

We would like to thank Marla Adkins-Heljeson and Liz Brosius of the Kansas Geological Survey who edited the manuscript, and Jennifer Sims and John Charlton, also with the Survey, who helped with the figures. The authors also would like to acknowledge the late Garner L. Wilde, who provided helpful discussions during the early stages of this study, and the continued encouragement of Evan Franseen. Excellent reviews by Gregory P. Wahlman and Karl Krainer were especially helpful in improving the final manuscript, and we are grateful for their time and expertise.

\section{References}

Baars, D. L., and Torres, A. M., 1991, Late Paleozoic phylloid algae--A pragmatic review: Palaios, v. 6, p. 513-515.

Babcock, J. A., 1977, Calcareous algae, organic boundstones, and the genesis of the upper Capitan Limestone (Permian, Guadalupian), Guadalupe Mountains, West Texas and New Mexico; in, Upper Guadalupian Facies, Permian Reef Complex, Guadalupe Mountains, New Mexico and West Texas, M. E. Hileman and S. J. Mazzullo, eds.: Permian Basin Section, Society of Economic Paleontologists and Mineralogists, Publication 77-6, p. 3-44.

Ball, S. M., Pollard, W. D., and Roberts, J. W., 1977, Importance of phylloid algae in development of depositional topography--reality or myth?; in, Reefs and Related Carbonates--Ecology and Sedimentology, S. H. Frost, M. P. Weiss, and J. B. Saunders, eds.: American Association of Petroleum Geologists, Studies in Geology Number 4, Tulsa, Oklahoma, p. 239-259.

Chafetz, H. S., 1986, Marine peloids--A product of bacterially induced precipitation of calcite: Journal of Sedimentary Petrology, v. 56, p. 812-817.

Chayes, F., 1949, A simple point counter for thin-section analysis: American Mineralogist v. 34, p. 1-11.

Cross, T. A., and Klosterman, M. J., 1981, Autecology and development of a stromatolitic-bound phylloid algal bioherm, Laborcita Formation (Lower Permian), Sacramento Mountains, New Mexico, U.S.A.; in, Phanerozoic Stromatolites, C. Monty, ed.: Springer-Verlag, Berlin, p. 45-59.

Crowley, D. J., 1969, Algal-bank complex in Wyandotte Limestone (Late Pennsylvanian) in eastern Kansas: Kansas Geological Survey, Bulletin 198, 52 p.

Elias, G. K., 1963, Habitat of Pennsylvanian algal bioherms, Four Corners area; in, A Symposium--Shelf Carbonates of the Paradox Basin, R. O. Bass and S. L. Sharps, eds.: Four Corners Geological Society, Fourth Field Conference, p. 185-203.

Forsythe, G. T. W., 2003, A new synthesis of PermoCarboniferous phylloid algal reef ecology; in, Permo-
Carboniferous Carbonate Platforms and Reefs, W. M. Ahr, P. M. Harris, W. A. Morgan, and I. D. Somerville, eds.: Society of Economic Paleontologists and Mineralogists, Special Publication No. 78, p. 171-188.

Ginsburg, R. N., and Lowenstam, H. A., 1958, The influence of marine bottom communities on depositional environment of sediments: Journal of Geology, v. 66, p. 310-318.

Johnson, J. H., 1946, Lime-secreting algae from the Pennsylvanian and Permian of Kansas: Geological Society of America, v. 57, p. 1,087-1,120.

Kirkland, B. L., Moore, C. H., Jr., and Dickson, J. A. D., 1993, Well preserved, aragonitic phylloid algae (Eugonophyllum, Udoteaceae) from the Pennsylvanian Holder Formation, Sacramento Mountains, New Mexico: Palaios, v. 8, p. 111120.

Konishi, K., 1961, Studies of Paleozoic Codiaceae and allied algae, Part I, Codiaceae: Science Reports of the Kanazawa University, v. 7, p. 159-261.

Konishi, K., and Wray J. L., 1961, Eugonophyllum, a new Pennsylvanian and Permian algal genus: Journal of Paleontology, v. 35, p. 659-666.

Laporte, L. F., 1960, Sedimentary facies of the Cottonwood limestone (Permian), northern midcontinent: Ph.D. dissertation, Columbia University, New York, 135 p. , 1962, Paleoecology of the Cottonwood limestone (Permian), northern midcontinent: Geological Society of America, Bulletin, v. 73, no. 5, p. 521-544.

Littler, D. S., Littler, M. M., Bucher, K. E., and Norris, J. N., 1989, Marine plants of the Caribbean-A field guide from Florida to Brazil: Smithsonian Institution Press, Washington, D.C., 263 p.

Pray, L. C., and Wray, J. L., 1963, Porous algal facies (Pennsylvanian), Honaker Trail, San Juan Canyon, Utah; in, A Symposium--Shelf Carbonates of the Paradox Basin, R. O Bass and S. L. Sharps, eds.: Four Corners Geological Society, Fourth Field Conference, p. 204-234.

Riding, R., 1993, Shamovella obscura: the correct name for Tubiphytes-obscurus (fossil): Taxon, v. 42, no. 1, p.71-73. 
Samankassou, E. and West, R. R., 2002, Construction versus accumulation in phylloid algal mounds-An example of a small constructed mound in the Pennsylvanian of Kansas, USA: Palaeogeography, Palaeoclimatology, Palaeoecology, v. 185 , p. $379-389$.

2004, Constructional and accumulational modes of fabrics in selected Pennsylvanian algal-dominated buildups in eastern Kansas, midcontinent, U.S.A.; in, PermoCarboniferous Carbonate Platforms and Reefs, W. M. Ahr, P. M. Harris, W. A. Morgan, and I. D. Somerville, eds.: Society of Economic Paleontologists and Mineralogists, Special Publication No. 78, p. 219-237.

Senowbari-Daryan, B., and Flugel, E., 1993, Tubiphytes Maslov, an enigmatic fossil: classification, fossil record and significance through time Part I: Discussion of late Paleozoic material; in, Studies on Fossil Benthic Algae, F. Barattolo, P. De Castro, and M. Parente, eds.: Bollettino della Societa Paleontologica Italiana, Special Volume 1, p. 353-382.

Simo, J. A., Wahlman, G. P. Stoklosa, M. L., and Beall, J. L., 2000, Heuco Mountains; in, Permian Platforms and Reefs in the Guadalupe and Hueco Mountains, P. M. Harris and J. A. Simo, eds.: Society of Economic Paleontologists and Mineralogists, Field Trip Guidebook No. 9, Symposium on Pennsylvanian-Permian Carbonate Platforms and Reefs, El Paso, Texas, $82 \mathrm{p}$.

Simo, J. A., Wahlman, G. P., Beall, J. L., and Stoklosa, M. L., 2001, Wolfcampian shelf-margins, Hueco Mountains, West Texas; in, Wolfcampian of West Texas (Permian Basin, Sierra Diablo and Hueco Mountains)--Shelfal and Periplatform Carbonate Reservoirs and Outcrop Analogs, E. L. Stoudt and D. J. Sivilis, eds.: Permian Basin Section, Society of Economic Paleontologists and Mineralogists, Publication 2001-41, Core Workshop and Field Trip Guidebook, p. 8-1 to 8-26.

Stockman, K. W., Ginsburg, R. N., and Shinn, E. A., 1967, The production of lime mud by algae in south Florida: Journal of Sedimentary Petrology, v. 36, p. 633-648.

Toomey, D. F., 1976, Paleosynecology of a Permian plant dominated marine community: Neues Jahrbuch fur Geologie und Palaontologie, Abhandlungen, v. 152, p. 118 .
Torres, A. M., 1995, Ivanovia tebagaensis was a cyathiform Permian codiacean membranous alga with dimorphic cortices: Journal of Paleontology, v. 69, p. 381-387. 1997, Reconstruction of a cyathiform Eugonophyllum, Upper Pennsylvanian, Palo Pinto County, Texas: Journal of Paleontology, v. 71, p. 493-499.

Torres, A. M., and Baars, D. L., 1992, Anchicodium Johnson-Branched or phylloid?: Journal of Paleontology, v. 66, p. 675-677.

Torres, A. M., West, R. R., and Sawin, R. S., 1992, Calcipatera cottonwoodensis, a new membranous late Paleozoic calcareous alga: Journal of Paleontology, v. 66, p. 678-681.

Wahlman, G. P., 1985, Lower Permian (Wolfcampian) Archaeolithoporella-Tubiphytes- sponge boundstones from the subsurface of West Texas; in, Paleoalgology, Contemporary Research and Applications, D. F. Toomey and M. N. Nitecki, eds.: Springer-Verlag, Berlin, p. 208215 .

, 1988, Subsurface Wolfcampian (Lower Permian) shelf-margin reefs in the Permian basin of West Texas and southeastern New Mexico; in, The Permian of the Midcontinent, W. P. Morgan and J. A. Babcock, eds.: Midcontinent Section, Society of Economic Paleontologists and Mineralogists, Special Publication No. 1, p. 177-204. 2001, Pennsylvanian-Lower Permian mounds and reefs in the Permian basin (West Texas-New Mexico)-Composition, evolution, distribution, and reservoir characteristics; in, The Permian Basin: Microns to Satellites, Looking for Oil and Gas at all Scales, J. J. Vveiros and S. M. Imgram, eds.: West Texas Geological Society, Publication 01-110, p. 57-64. 2002, Upper Carboniferous-Lower Permian (Bashkirian-Kungurian) mounds and reefs; in, Phanerozoic Reef Patterns, W. Kiessling, E. Flugel, and J. Golonka, eds.: Society of Economic Paleontologists and Mineralogists, Special Publication No. 72, p. 271-338.

Wray, J. L., 1964, Archaeolithophyllum, an abundant calcareous alga in limestones of the Lansing Group (Pennsylvanian), southeastern Kansas: Kansas Geological Survey, Bulletin $170,13 \mathrm{p}$. 